\title{
Managing Digital Marketing Communication of Coffee Shop Using Instagram
}

\author{
https://doi.org/10.3991/ijim.v14i05.13351 \\ Dewi K Soedarsono $(\square)$ \\ Telkom University, Bandung, Indonesia \\ soedarsonodewik@gmail.com \\ Bahtiar Mohamad \\ University Utara Malaysia, Kedah, Malaysia \\ Adamu Abbas Adamu \\ Curtin University, Miri, Malaysia \\ Kennia Aline Pradita \\ Telkom University, Bandung, Indonesia
}

\begin{abstract}
This paper focuses on managing the digital marketing communication of coffee shop using the Instagram. The Instagram application offer a great advantage such as quick and cheap marketing communication tools, particularly in promoting the product, disseminating advertisement and brand awareness. Previous study highlighted that managing marketing communication via Instagram is a strategic tool to inform, persuade and remind consumers about what they offer. However, there is limited number of empirical studies on Instagram as a marketing communication tools on how efficiencies of Instagram application in managing digital marketing communication strategies to the customers. Therefore, this paper will enlighten the issues related to the application of Instagram as a marketing tool in the coffee shop business. The content analysis and semi-structured interview has been employed to gain in-depth knowledge from the owner, marketing staffs and marketing consultant who have experiences in managing the digital marketing communication strategy. The findings of the study revealed that Instagram application has become an effective marketing communication tools to disseminate the promotional message to the customers in quick way dan cost efficient as compare to the traditional media.
\end{abstract}

Keywords - Instagram, marketing communication, promotion, digital marketing.

\section{$1 \quad$ Introduction}

At the current times, the development of communication technology such as Instagram has been used by companies to carry out various promotion activities to attract 
consumers [1],[2]. The social media such as Facebook, Instagram and Youtube is among of the marketing tools for the business to leverage their profit. Marketing communication covers a wide range of external communication that includes personal selling, advertising, publicity, public relations, reseller support, and merchandising, product sampling and packaging changes. The main issues in marketing communication are a channel of communications that can be used in marketing programs.

In today's digital world, marketing has touched the use of social media in implementing marketing strategies. At least now, almost all companies or business people utilize social media starting from conveying information, persuading, to offer their products to consumers. Social media is currently widely used by business people as one of its marketing communication media. Before marketing communication is carried out, there are strategies that support each other to achieve success according to the desired target [3].

It also widely used by the business entities in Indonesia. For example, KOZI coffee shop in Bandung that regularly uses Instagram as its marketing communication tools. As a coffee shop that follows the trend of social media technology, KOZI uses Instagram as a marketing communication media in promoting its products to consumers. This study will link the communications tools (i.e. Instagram) that related to marketing activities. Therefore, this paper will investigate the KOZI's marketing communication strategy planning through Instagram social media includes message strategies and strategy's media.

\section{The Literature Review}

\subsection{KOZI coffee at a glance}

The Instagram account named @ kozi. coffee has been followed by 11.7K users and currently has posted about 1,043 posts. Their Instagram account does not only communicate through text, but also through photos and videos which show the uniqueness of each post beautified with Instagram features. KOZI's Instagram account is directly handled by the owner in managing the posts photos and videos. It is to maintain the characteristics of content posted in Instagram daily.

KOZI is a new coffee shop in Bandung, which was established in 2015 and currently KOZI has four branches throughout Bandung. Interestingly, from the four branches, KOZI has a different concept based on the uniqueness of each location. For instance, Jalan Gudang Selatan branch, consumers will enjoy the coffee experience in a 'warehouse' concept with a messy impression with a calm atmosphere.

While, it's different at KOZI 2.0 concept where place is more like a home because the place previously was a house. The walls were decorated with paintings and owner's photographs of the house with the warmer and calm atmosphere. Furthermore, KOZI 3.2 brach that located in the right corner of the Malacca Hotel has a minimalist concept and looks more formal and equipped with a coffee bar made from marble. Finally, KOZI 6.0 branch which is located in Bandung Creative Hub offered learning 
atmosphere with supported by long chairs and tables decorated with study lights and, suitable for students.

\subsection{The concept of marketing communication}

Marketing communication includes five functions such as advertising sales promotion, direct mail, sponsorship and personal sales [4]. These five functions help the organisation to communicate effectively to their external stakeholders. For example, marketing communication used by companies as strategic tools to inform, persuade and remind consumers about what they offer [5].

In the current development Hughes and Fill [6] believes the ways to persuade customers to think and behave in particular ways have changed. Persuasion is now regarded as one of a number of tasks that an organisation needs to accomplish through its social media such as Instagram. For example, providing information, listening, informing and reminding customers are just some of the complexities associated with contemporary interpretations and usage of marketing communications. The emphasis has shifted from a 'promoting to' to a 'communicating with' focus [6]. While the origins of the promotional mix may have provided a basis for firms, today is the complex communications environment of today suggests that consumers care little as to what terms are used to describe the forms through which they receive communications.

Many practitioners on of marketing communication regard advertising as a vital and salient component of the communication mix [7]. Franzen [8] describes advertising as a process of relatively indirect persuasion, based on information about product benefits, designed to create favourable impressions that 'turn the mind toward' purchase. Moreover, sales promotion is often regarded as 'additional activities which support sales representatives and distributors' [9] to influences customer perception towards products and services.

According to Anderson [10], marketing communications is view primarily as a one-way information mechanism in the 'traditional' marketing mix by which the firm attempted attempts to convince the target consumer audience of the benefits of the firm's products. Usually, decisions concerning communication messages were the responsibility of 'in-house' or 'external agencies', and the sales personnel were played a role to disseminate of these messages [10] [11]. Nevertheless, due to the increased sophistication of consumers and advancements in social media, the effectiveness of the traditional method of marketing communication was declined significantly [5] [11] [12]. These factors have necessitated marketing communication tools for the organization, as well as providing the ability for the organisation to develop a more intimate relationship with its target stakeholders through the social media such as Instagram.

More recently, studies have identified successful marketing strategies that apply to small business [13]. The study reported that new media is an effective channel to promote business and recommended that organizations should create their own websites page, Facebook page, Instagram and YouTube to promote themselves and interact with customers. In fact, new media environments are characterized by streaming 
consumption, social media interactions and multitasking [14]. Under this circumstance, organizations are vested with the responsibility to satisfy both social clients and corporate clients in this competitive era [15]. In line with the above review, we proposed the following research question.

Research Question: How do KOZI use marketing communication strategies on Instagram?

\section{Research Method}

In line with the interpretivist philosophy, we used two research approaches to collect data in this study. More specifically, KOZI Coffee has been chosen as the subject of research to find out its marketing communication strategies carried out on Instagram. The authors' explore the marketing communication strategy of kozi coffee based on the unique concepts of each their branches. The unit of analysis of the research is the marketing communication strategy of KOZI on Instagram. This research was conducted in all four branches of KOZI Bandung, precisely at Gudang Selatan Street No.22 as KOZI 1.0, KOZI 2.0 tin Street Hill Dago North, KOZI 3.2 located in Hotel Malacca and KOZI 6.0 at the Bandung Creative Hub.

We contacted the chief executive officer of KOZI for approval of our study to ensure we follow the ethical requirement of conducting research with human beings. Subsequently, we used purposeful non-probability sampling which is grounded on the assumption that researchers who wants to understand, discover and gain insight must select a sample from which the most can be learned [16], [17]. A total number of seven informants from marketing communication department, the owner, and marketing consultants were interviewed. The duration of the interview is from 30 minutes to 1 hour 30 minutes. We used an interview guide with open ended questions to allow the informants to provide more details on KOZIs marketing strategies. A small radio for recording answers was used and all the interview data was transcribed [18]. Similarly, we also applied a content analysis approach at this stage. This is to ensure that we capture KOZIs digital marketing strategies on digital media. More specifically, the content analysis involved the observing content on Instagram of KOZI that includes photos and captions.

\section{$4 \quad$ Result and Discussion}

In this section, we present the findings of our research. Particular, the discussion of the results from the semi-structured interviews and content analysis. The findings indicated that the marketing strategies used by KOZI is effective in generating customers. However, some of the informants have mix-feeling. The following are the results of interviews that researchers obtained. 


\subsection{KOZI marketing communication strategy on instagram}

In today's digital world, marketing has touched the use of social media in implementing marketing strategies. One of the informants express the opinion:

"At least now, almost all companies or business people utilize social media starting from conveying information, persuading, to offer their products to consumers. Social media is currently widely used by business people as one of its marketing communication media". (Informant 3)

Before marketing communication is carried out, there are strategies that support each other to achieve success according to the desired target. In line with the question on KOZI marketing strategies, one of the informant illustrated:

"KOZI's marketing communication strategy planning through Instagram social media includes message strategies and strategy's media. In marketing a product, our organization carefully plan strategies that are capable of being dynamic in change". (Informant 1)

Organizations or companies need a strategy and marketing plan to achieve a goal. Through the interviews conducted by the author to the informant, the key informant gave an answer about the matters related to the strategy of the message being carried out, among others, the contents of the information and creative forms of the Instagram message KOZI.

\subsection{The content of instagram}

In the interviews that have been conducted, the key informant conveyed the contents of the information he wanted to convey to consumers regarding KOZI through Instagram as a coffee shop with a service model that was close to consumers.

"The content of another information that you want to convey about KOZI is the selection of a unique place, because in choosing a place that is not public, and the concept of a different place is used as a strategy carried out by KOZI". (Informant 5)

According to Kennedy and Soemanegara [19] marketing communication can be expressed as a communication activity that aims to convey messages to consumers by using various media, with the hope that communication can produce changes in knowledge, changes in attitude, and changes in desired actions. In line with the above assertion, some of the informant implore that:

KOZI needs to ensure that all Instagram photos performance are measured on a regular basis to ascertain the level of changes it has garnered toward a particular marketing strategy. Although, they are of the opinion that Instagram help in improving KOZI's marketing strategies. (Informants 2, 4 \& 7)

Marketing communication according to Tjiptono [20] marketing activities that try to disseminate information, influence, persuade, and or remind the target market of companies and services willing to ask, buy, and loyal to the services offered by the company concerned. Marketing communication is an effort to strengthen the customer loyalty to a product. Communication activities use a number of media and various channels in the hope that the achievement of changes in knowledge, attitude changes, 
and behavioral changes can be used as a strategy to achieve company goals in increasing income. During the interview, another informant demonstrated that:

"with KOZI, the coffee shops is designing a marketing communication strategy so that information can be delivered to the KOZI target audience, KOZI using social media and choose Instagram as a communication medium for marketing to consumers". (Informant 4)

Based on the results of the research and the data that has been collected, the following is the result of the researchers' analysis of KOZI's marketing communication strategy through Instagram social media. The advantage of using social media as a means of marketing communication is that consumers are able to get information about a product according to their wants and needs. In addition, social media can also connect between companies and customers, making it easy for customers to interact with company.

\subsection{The creative forms of the Instagram}

We perform an analysis investigating whether KOZI use of Instagram social media as one of its marketing communication media is effective in creating marketing power through the use of visual language and words. This is supported by an explanation of Instagram, which is a type of social media sharing where users can specifically share images and videos to fellow users. Instagram also has the strongest bonding strength compared to other social media through Instagram features that prioritize visual communication can attract users to linger access to the application this.

The use of Instagram social media is considered successful and is able to convey marketing communication well. Especially in visual communication because the current habits of the audience when they want to find something must see from the visual form first. This was also conveyed by a respondent (marketing consultant), as a supporting informant in this study that businesses with a segment of young people will tend to use Instagram social media because now when we want something to taste it usually sees its visual form before coming to the place. According to Machfoedz [21] in the message strategy, there is information content and the message's creative form. Before designing the content and form of the message, the target market segment must be selected first. Target markets are chosen because they have background characteristics that cause similarities in process and consumption behavior. Marketers must be able to design message strategies that are suitable for the target market.

In delivering messages through Instagram, the content of information that KOZI wants to convey is as a coffee shop with a service model that is close and familiar with consumers, to the barista who is willing to teach coffee making. This statement is supported by marketing consultant statement that the barista is good communicative because when consumers come to the coffee shop not only come and order coffee, but can communicate with the barista about what coffee menus are available and recommended types of coffee directly from the barista.

Besides that, KOZI wants to be known as a place that has a comfortable atmosphere with a unique café concept in choosing unusual places because KOZI chooses places that are not strategic and veiled, until the concept of place is different in each 
of its branches. This was supported when researchers interviewed one of KOZI's consumers, who stated that KOZI was a relaxing place with different KOZI concepts, even consumers could spend up to hours when coming to KOZI because of the comfortable.

In addition to some of the information content that KOZI wants to convey, it becomes a strategy related to the creative form of the message packaged by KOZI through Instagram @ kozi.coffee, which is a relaxed, eccentric, and weird photo and caption content. According to Machfoedz [21] there are two types of messages to attract consumers, namely first informational or rational, both emotional and transformational. An appeal informational marketing effort to present the information about the product to consumers who are applied to the process of a rational purchase. Informational appeal can be evidenced by writing captions to the photos posted related KOZI atmosphere, the price of coffee, to the barista who was on duty at KOZI delivered with slang that is more relaxed and not stuffy. In addition to a photo caption that its use of everyday language, making Instagram @ kozi coffee is seen not as a business account but someone's personal account, it is used as a strategy for Instagram KOZI more interactive with its target audience, which is where the discussion of the products offered only 50 percents. This statement is supported through what was conveyed by the KOZI customer at the time of the interview when the author was at KOZI that the use of the caption via Instastory @ kozi coffee uses an eccentric language that is not even rigid as most business models others.

The interactive form done by Instagram @ kozi coffee is in the form of questions relating to the uploaded photo, to caption writing that provokes the audience to respond in the form of likes and comments. This is what attracts consumers to interact with Instagram KOZI and is supported by a statement stating that KOZI in creating interaction is good enough. According to respondent (mareting consultant), KOZI adapts to the era of two-way communication, with the explanation that when the captions and photos uploaded look normal, the audience's interest in the content becomes common, while when the photo is unique with the addition of the captive caption like KOZI's strategy then this will attract consumers to comment on content posted.

While emotional or transformational attraction is an attempt to influence consumer suggestions that will use products offered by KOZI through content. The content in question is the photo content shared in the form of photos of all KOZI places, showing the atmosphere of drinking coffee at home, next to the hotel, and the atmosphere in the warehouse. This was confirmed by KOZI consumers that @ kozi coffee often uploaded photos of the atmosphere of all KOZI branches.

Next is a photo of the product, whichever coffee is available at KOZI, packed with a distinctive touch of KOZI weirdness, to photos of activities carried out by consumers who come. Through creative forms, the message can attract the target audience to visit KOZI. Respondent (marketing consultant) supported this that KOZI's atmosphere was portrayed through Instagram@ kozi coffee where consumers can take coffee photos and even take selfies. In media strategy there are two types of strategies to convey messages to consumers. First, the choice of media which channel is used to convey the message. Second, consumer loopholes are the time and place for marketers to market their products to get consumers more leverage [21]. 
The media strategy explains that there are two subjects that are used to convey the contents of information to the target audience. First is the media is the channel used to convey the message. Second, the slit consumer is to convey messages in order reach maximum reach [21]. The selection of Instagram is considered successful in conveying marketing communications well, because Instagram plays with a visual language that can have the strongest binding power compared to be other social. Based on the results of the research, the advantages of Instagram are made by KOZI to be able to maintain loyalty from its customers, such as consumers who come with various activities carried out at KOZI, as well as repeated consumer arrivals, to get to know consumers who often come to KOZI. Besides that, to get the maximum reach of the target audience, KOZI complies with the behavior of the target audience which currently tends to use Instagram as a platform to find place references, this is also one of the opportunities that make Instagram a KOZI marketing communication media strategy. The next strategy is the use of Instastory feature, which is now a trend considered capable of reaching many viewers, arguing that the advantages of Instastory are playing on visual moves so that the audience is interested to see the contents of Instastory uploaded by Instagram KOZI in the form of photos to videos that show the atmosphere at KOZI at that time. This statement was conveyed by Santriana, where the marketing communication strategy must be adjusted to the target audience, which is what KOZI does in making marketing communication strategies in the digital marketing era that adapts to the target audience.

Besides using Instastory, the use of hashtags is also done by Instagram @ kozi coffee to reach the target audience. Because it is considered to facilitate the search for places, especially the coffee shop KOZI. KOZI also sets the time for uploading photos on the @ kozi coffee Instagram account, every day, from 6:00 to 22:00. Based on research, there is no specific schedule for how many photos and exactly what time should be posted every day by Instagram @ kozi coffee.

\section{Conclusion}

For digital contents, KOZI coffee shop designs a marketing communication strategy to deliver information about KOZI to the target audiences using communicative language style. KOZI uses Instagram as one of its marketing communication media because it is considered to have marketing power through the use of visual language and words. KOZI coffee business targeting young people segment tends to use Instagram since this segment will have to see the visual appearance on Instagram before deciding to go to the shop. In delivering the messages on Instagram, @kozi coffee uses a strategy of creative message through the photos and captions which are relaxed, eccentric, and even weird. The informational attractions can be proven through the captions on the posted photos about the atmosphere, the coffee prices, and the incharged barista at KOZI delivered in a more relaxed and unrigid language. The use of everyday language make @kozi coffee does not look like a business account; instead, it looks like a personal account. It is intended as a strategy to make KOZI Instagram account more interactive with its target audience. To be interactive, they question 
about the uploaded photos and write the captions that provoke the target audiences to like and comment. It is what attracts consumers to be interactive in their Instagram account. Meanwhile, emotional or transformational attraction is an attempt to drive consumers who probably will consume the products offered by KOZI on Instagram. The contents are the photos capturing all places at KOZI, showing the atmosphere of drinking coffee at home, beside the hotel, and the atmosphere in their warehouse. In addition, they also upload the photos of the coffee products available at KOZI, packed with a distinctive touch of KOZI weirdness, and photos of visitors' activities. Therefore, to attract the target audience to visit KOZI, they can implement the strategy of delivering the creative messages about KOZI's atmosphere portrayed on Instagram showing that the consumers can take pictures of coffee and even do the selfies photos.

Message strategies include the contents of communication information and creative forms of messages delivered via Instagram KOZI. Contents the information you want to convey to consumers about KOZI via Instagram is a coffee shop with a service model that is close to consumers, offering a place with a comfortable atmosphere, with a unique café concept because it is different in each of its branches. The creative form of the message in the form of content such as photos and captions posted on Instagram@kozi coffee is unique because it shows the relaxed, eccentric, and strange side of KOZI. The content in question is product content, atmosphere, and consumers who come. The choice of language for caption writing on Instagram @ kozi coffee uses non-formal language for reasons more interesting than the use of corporate language because it feels boring. Because of this, it makes Instagram KOZI more interactive with its customers. The media strategy undertaken by KOZI includes media selection and Instagram target audience KOZI. The selection of Instagram media as a medium of marketing communication by KOZI because Instagram plays on visual language and words that have the strongest binding power among other social media, and become an opportunity to maintain consumer loyalty.

KOZI's target audience is also adjusted to the habits of the target audience, where audiences currently tend to choose Instagram as a platform to find place references, using the Instastory feature that has become a current trend and hashtag feature to make it easier for consumers to find coffee places that refer to KOZI, and the timing of posts at $6 \mathrm{am}$ to $10 \mathrm{pm}$ is considered to reach the target audience of KOZI.

\section{References}

[1] De Veirman, M., Cauberghe, V., \& Hudders, L. (2017). Marketing through Instagram influencers: the impact of number of followers and product divergence on brand attitude. International Journal of Advertising, 36(5): 798-828. https://doi.org/10.1080/02650487. 2017.1348035

[2] Chen, H. (2018). College-aged young consumers' perceptions of social media marketing: The story of Instagram. Journal of Current Issues \& Research in Advertising, 39(1): 22-36. https://doi.org/10.1080/10641734.2017.1372321

[3] Mohamad, B., Rageh, A., \& Bidin, R. (2017). Corporate identity management and employee brand support: Enhancing marketisation in higher education sector. Jurnal Komu- 
nikasi: Malaysian Journal of Communication, 33(3), 178-195. https://doi.org/10.17576/ JKMJC-2017-3303-11

[4] van Riel, C.B.M. (1995). Principles of Corporate Communication, Hemel Hempstead: Prentice-Hall.

[5] Holm, O. (2006). Integrated marketing communication: from tactics to strategy. Corporate Communications: An International Journal, 11(1), 23-33. https://doi.org/10.1108/13563 280610643525

[6] Hughes, G. and Fill, C. (2007). Redefining the nature and format of the marketing communications mix. The Marketing Review, 7(1) 45- 57. https://doi.org/10.1362/14693470 $7 \mathrm{X} 180677$

[7] Mohamad, B., Nguyen, B., Melewar, T. C., \& Gambetti, R. (2018). Antecedents and consequences of corporate communication management (CCM) An agenda for future research. The Bottom Line, 31(1), 56-75. https://doi.org/10.1108/BL-09-2017-0028

[8] Franzen, G. (1994). Advertising Effectiveness: Findings from Empirical Research, Henleyon-Thames: NTC Publications.

[9] Jefkins, F. (1993). Modern Marketing, 3rd edition, Financial Times Management.

[10] Anderson, P.H. (2001). Relationship development and marketing communication: An integrative model. The Journal of Business and Industrial Marketing, 16(3), 167-182. https://doi.org/10.1108/08858620110389786

[11] Kim, I., Han, D. and Schultz, D.E. (2004). Understanding the diffusion of integrated marketing communications. Journal of Advertising Research, 44(1) 31-45. https://doi.org/10.1017/S0021849904040024

[12] Pitta, D.A., Weisgal, M. and Lynagh, P. (2006). Integrating exhibit marketing into integrated marketing communications. Journal of Consumer Marketing, 23(3), 56-166. https://doi.org/10.1108/07363760610663312

[13] Lam, S., \& Yeung, D. (2018). Identify successful marketing communication strat-egies that apply to a small hair salon.

[14] Chan-Olmsted, S. and Wolter, L.C., 2018. Emotional Engagement in a New Mar-keting Communication Environment. The Handbook of Communication Engagement, pp.421437. https://doi.org/10.1002/9781119167600.ch29

[15] Ashraf, M. Z. (2018). Digital marketing communication: a case study on the satis-faction level of the service of Roebuck Communications.

[16] Abu Bakar, H., Mohamad, B., Halim, H., Subramaniam, C., \& Choo, L. S. (2018). Shared cultural characteristics similarities in Malaysia's multi-ethnic society. Journal of Intercultural Communication Research, 47(3), 243-267. https://doi.org/10.1080/17475759.2018. $\underline{1460274}$

[17] Merriam, S. B. (2009). Qualitative research: A guide to design and implementation. Journal of Chemical Information and Modeling. 53.

[18] Creswell, J. (2009). Research design: Qualitative, quantitative, and mixed methods approaches. SAGE Publications, Incorporated.

[19] Kennedy, John E, R, Soemanegara. 2006. Marketing Communication. Jakarta: PT. Buana Ilmu Populer

[20] Tjiptono, F. (2008). Service management mewujudkan layanan prima. Yogyakarta: Andi.

[21] Machfoedz, Mahmud. 2010. Komunikasi Pemasaran Modern. Yogyakarta: Cakra Ilmu. 


\section{Authors}

Dewi K Soedarsono is a lecturer at Faculty of Communication and Business, Telkom University. Before joining Telkom University, she worked as a lecturer at several private universities in Jakarta and Bandung. She also involved in the research related to community social responsibility, management communication and social media. Email: soedarsonodewik@gmail.com

Bahtiar Mohamad is an Associate Professor at School of Multimedia Technology and Communication, Universiti Utara Malaysia. His publications and research interests in the recent years have focused on Corporate Communication and Public Relations in the areas of corporate identity, corporate image, corporate branding and crisis communication. Email: mbahtiar@uum.edu.my

Adamu Abbas Adamu is Lecturer at the Department of Marketing, Faculty of Business, Curtin University, Malaysia. He has previously worked with Hussaini Adamu Federal Polytechnic, Kazaure, Jigawa State, Nigeria. His primary research interests include internal crisis communication, scale development, measurement and evaluation in public relations and cross-cultural communication. Email: adamu.abbas@curtin.edu.my

Kennia Aline Pradita is a marketing graduate from Faculty of Communication and Business Telkom University. She works in Mercure Hotel Jakarta as a content creator. Email: kenniaaline@gmail.com

Article submitted 2020-01-22. Resubmitted 2020-01-22. Final acceptance 2020-02-03. Final version published as submitted by the authors. 